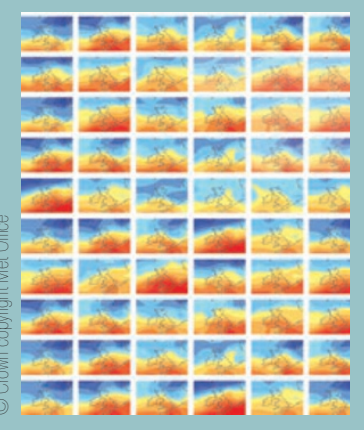

Cover design by Karen Moore

Nature Reports Climate Change

EDITORIAL OFFICE

Editor: Olive Heffernan

Copy Editor: Anna Barnett

Production Editor: Alexandra Hardy

Art Editor: Karen Moore

Web Production Editor: Manpreet Mankoo

MANAGEMENT OFFICE

Managing Director: Steven Inchcoombe

Publishing Director: David Swinbanks

Publisher: Jason Wilde

Associate Publisher: Emma Green

Editor-in-Chief, Nature Publications: Philip Campbell

Marketing Manager: Louise Porter

Managing Production Editor: Donald McDonald

Senior Production Editor: Derna Simpson

Senior Copy Editor: Jane Morris

Advertising Manager, Physical Sciences: Simon Allardice

The Macmillan Building, 4 Crinan St

London N1 9XW, UK

Tel: +44 (0) 2078334000

e-mail: nature@nature.com

VISIT NATURE REPORTS

CLIMATE CHANGE ONLINE

World Wide Web

http://www.nature.com/reports/climatechange

SUBSCRIPTIONS AND CUSTOMER SERVICES

For UK/Europe (excluding Japan):

Nature Publishing Group, Subscriptions, Brunel Road,

Basingstoke, Hants, RG21 6XS, UK.

Tel: +44 (0) 1256329242 .

Subscriptions and customer services for

Americas - including Canada, Latin America and the

Caribbean: Nature Publishing Group,

Subscription Department, P0 Box 5161, Brentwood,

TN 37024-5161

Tel: (800) 5242688 (US) or 6158505315

(outside the US).

\section{SMALL PACTS ARE NO BIG DEAL}

Hopes have faded that a legally binding climate treaty will emerge from next month's UN conference in Copenhagen, with even some of its most ardent backers looking to reset the deadline for agreeing a deal to early 2010. If December's summit fails in this regard, there will be some obvious culprits: the global recession, which has made nations reluctant to commit cash to the problem, and the US Senate, where horn-locking among lawmakers has delayed the passage of domestic legislation.

But even without these bumps in the road - which were perhaps unforeseen when the Bali Roadmap was laid out in 2007 - the challenge set out for negotiators in Copenhagen may have been too great from the outset. In this issue, Nature Reports Climate Change looks at the UN summit from the perspective of researchers who study cooperation (see page 130), some of whom argue that trying to get an effective multi-faceted treaty agreed between 192 nations is a waste of time. Many behavioural economists say — and common sense dictates — that a strong agreement would be more easily negotiated between fewer parties.

The legitimacy of this claim is evidenced by the recent bilateral talks between two of the world's major greenhouse gas emitters, China and India, who in late October signed a five-year pact to present a united front at international climate negotiations.

The US is now seeking to broker similar agreements with both nations in the coming month, and strongly believes that such bilateral deals — with Russia and Brazil also - will form the basis of an international agreement in December. From the perspective of political haggling, this makes sense. Cooperation in Copenhagen will only be achieved if those responsible for the majority of emissions can agree on how to apportion responsibility for climate change fairly, as well as on the carrots and sticks that will ensure compliance, rather than encourage free-riding.

While bilateral — or small multilateral — agreements may be more effective in this regard, that in no way means that the Copenhagen conference is, in itself, a waste of time. An international agreement on how to resolve climate change equitably would, after all, carry more clout than deals brokered behind closed doors. But this is no mean feat, requiring resolution of several key issues: ambitious emissions targets for the world's rich, the ability of emerging economies to slow their emissions growth and the transfer of capital from rich to poor nations for adaptation and green technology development.

Smaller deals can bring us a long way to achieving agreement on those issues of equity, but they alone cannot solve the problem of climate change. Without an international deal in place, lawmakers risk setting aside the notion of controlling global greenhouse gas emissions in order to limit warming to within a specific temperature threshold. That is - after all — the intended objective of a climate deal.

\section{RESEARCH HIGHLIGHTS}

124 Biodiversity and ecology Ocean species shift

Olive Heffernan

Technology

Risky business

Olive Heffernan

Society

Green and greedy

Olive Heffernan

Regional climate

Southeast drought

Olive Heffernan

125 Paleoclimate

All creatures small

Alicia Newton

Earth science

Refining the future

Anna Armstrong

\section{COMMENTARY}

\section{Keeping prediction} in perspective

Mike Hulme, Roger Pielke Jr and Suraje Dessai

\section{NEWS FEATURE}

\section{No easy way out}

Anna Barnett

\section{FEATURE}

130 The climate change game

Mason Inman 